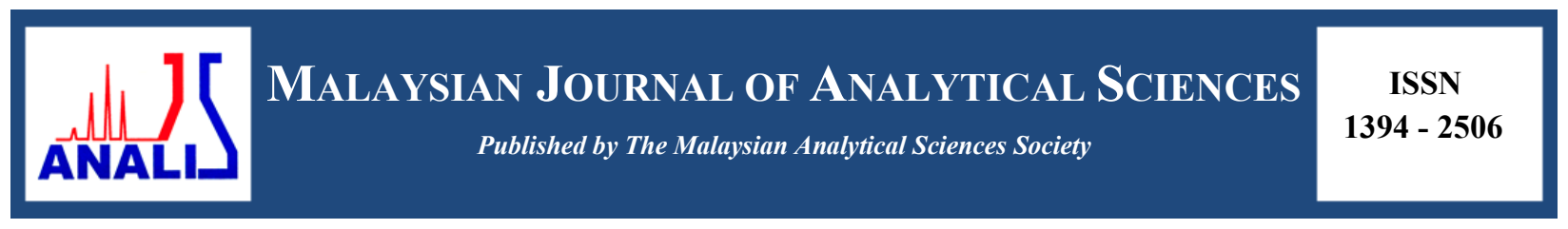

\title{
POTENTIOMETRIC STUDY OF RHENIUM(V) COMPLEX FORMATION WITH AZATHIOPRINE AND CEFTRIAXONE
}

\author{
(Kajian Potentiometri Penghasilan Kompleks Rhenium(V) dengan Azatioprina dan Ceftriaxon) \\ Gamal Abdelaziz Hussein Gouda ${ }^{1 *}$, Gomaa Abdelgawad Mohammed Ali ${ }^{1,2}$ \\ ${ }^{I}$ Chemistry Department, Faculty of Science, \\ Al-Azhar University, 71524 Assiut, Egypt \\ ${ }^{2}$ Faculty of Industrial Sciences \& Technology, \\ Universiti Malaysia Pahang, Gambang, 26300 Kuantan, Malaysia \\ *Corresponding author: ggouda73@mail.ru
}

Received: 3 March 2017; Accepted: 17 September 2017

\begin{abstract}
The behavior of complex formation of $\operatorname{Re}(\mathrm{V})$ metal ion with azathioprine (AZ) and ceftriaxone (CE) as medicinal drugs has been investigated potentiometrically in $0.3 \mathrm{M}$ hydrochloric acid. The stability constant of the prepared complexes has been determined and calculated at various temperatures. The obtained results showed that $\operatorname{Re}(\mathrm{V})-\mathrm{AZ}$ system showed the formation $1: 2$, 1:3 and 1:4 complexes, while $\operatorname{Re}(\mathrm{V})$-CE showed only 1:1 and 1:2 complexes. The complex formation suggests a successive displacement of the chloride molecules from the coordination sphere of the central ion by the AZ ligand. In addition, the effect of temperature on the complexes formation of $\operatorname{Re}(\mathrm{V})$ with $\mathrm{AZ}$ and $\mathrm{CE}$ was investigated. The entropy and enthalpy changes showed a favorable and exothermic process, respectively. The kinetic parameters of the formation complex process were calculated and discussed.
\end{abstract}

Keywords: rhenium(V), drugs, potentiometry, complex formation, stability constant

\begin{abstract}
Abstrak
Tingkah laku penghasilan kompleks ion logam $\operatorname{Re}(\mathrm{V})$ dengan azatioprina (AZ) dan ceftriaxon (CE) sebagai ubat - ubatan telah dikaji secara potentiometri dalam $0.3 \mathrm{M}$ asid hidroklorik. Pemalar kestabilan terhadap kompleks yang dihasilkan telah ditentukan dan dikira pada pelbagai tahap suhu. Hasil yang diperoleh menunjukkan bahawa sistem $\operatorname{Re}(\mathrm{V})-\mathrm{AZ}$ mempamerkan penghasilan kompleks 1:2, 1:3 dan 1:4, sementara $\operatorname{Re}(\mathrm{V})$-CE mempamerkan hanya kompleks 1:1 dan 1:2. Penghasilan kompleks mencadangkan satu anjakan molekul klorida berturut-turut dari lingkungan koordinasi ion tengah oleh ligan AZ. Di samping itu, kesan suhu pada pembentukan kompleks Re(V) dengan AZ dan CE telah dikaji. Perubahan entropi dan entalpi menunjukkan proses yang baik dan eksotermik. Parameter kinetik proses penghasilan kompleks turut dikira dan dibincangkan.
\end{abstract}

Kata kunci: rhenium(V), ubat, potentiometri, penghasilan kompleks, pemalar kestabilan

\section{Introduction}

The stability of complexes with medicinal drugs plays a major role in their biological and chemical activities. This is due to that, the medicinal drugs have various functional groups, which can bind to metal ions present in the human body [1,2]. The azathioprine (AZ) is an immunosuppressive drug used in organ transplantation and autoimmune diseases $[3-5]$ while the ceftriaxone (CE) is effective against a wide variety of Gram-positive and Gram-negative bacteria [6 - 9]. Very few works investigated the stability constant and thermodynamic parameters $(\Delta \mathrm{G}, \Delta \mathrm{H}$ and $\Delta \mathrm{S}$ ) of Re-Az and Re-CE complexes at different temperatures. The complex formation behavior of AZ with various metal ions has been studied by the potentiometric titration method [10]. AZ is found to form 2:1 
complexes with $\mathrm{Co}(\mathrm{II}), \mathrm{Cu}(\mathrm{II})$ and $\mathrm{Ni}(\mathrm{II})$, in the stability order of $\mathrm{Cu}(\mathrm{II})>\mathrm{Ni}(\mathrm{II})>\mathrm{Co}(\mathrm{II})$. The effect of various divalent cations on the encapsulation efficiency of gellan gum and to probe the underlying mechanisms responsible for drug loading efficiency. Spherical beads containing AZ were prepared from deacetylated gellan gum by ionotropic gelation method [11]. The anti-rheumatic studies on $\mathrm{AZ}$ have also involved its $\mathrm{Cu}(\mathrm{II})$ complexes as the possible active form and the stoichiometry and the stability constants of AZ metal complexes, even with that of $\mathrm{Cu}(\mathrm{II})$, have been determined [12].

$\mathrm{CE}$ is evaluated as a corrosion inhibitor for carbon steel alloys in the presence of $0.5 \mathrm{M}$ hydrochloric acid $(\mathrm{HCl})$ at different concentrations, i.e., 10-50 ppm and different temperatures [13]. Studies of the mechanism, kinetics and thermodynamic constants of $\mathrm{VO}$ (II) and $\mathrm{Cu}(\mathrm{II})$ complexes with $\mathrm{CE}$ in the $\mathrm{pH}$ range of $2-5$ at temperatures of 303 , 313,323 and $333 \mathrm{~K}$, using reversed phase HPLC and ion exchange HPLC were reported [14]. CE degradation in aqueous solution was studied at 310 and $353 \mathrm{~K}$ in acidic, basic and neutral conditions. Stability constants of $\operatorname{Re}(\mathrm{V})$ metal complexes with selected medicinal drugs adenosine, isoniazid and metformin hydrochloride have been determined using a $\mathrm{pH}$ metric titration technique in aqueous $\mathrm{HCl}$ at different temperatures and an ionic strength of $0.2 \mathrm{M}$ [15]. The process of complex formation of $\operatorname{Re}(\mathrm{V})$ ion with 2-mercapto-pyridine was investigated potentiometrically by evaluating formation the equilibrium and stability constants of the metal complex at the temperature range of 273-338 K [16].

In the present study, the formation equilibrium investigations were extended to the stoichiometry and stability constants of complex formation of $\mathrm{AZ}$ and $\mathrm{CE}$ (Scheme 1) with $\mathrm{Re}(\mathrm{V})$ metal ion in aqueous $\mathrm{HCl}$ at different temperatures. Moreover, the kinetic parameters of the complex formation were determined and discussed.<smiles>Cn1cnc([N+](=O)[O-])c1Sc1ncnc2nc[nH]c12</smiles>

Azathioprine<smiles>CON=C(C(=O)NC1C(=O)N2C(C(=O)O[N+])=C(CSc3nc(=O)c(ON)nn3C)CSC12)c1csc(N)n1</smiles>

Ceftriaxone

Scheme 1. The chemical structures of the studied drugs

\section{Materials}

\section{Materials and Methods}

Potassium perrhenate $\left(\mathrm{KReO}_{4}\right)$ and iodine were purchased from Aldrich and Fluka, respectively. $\mathrm{KReO}_{4}$ was converted to $\mathrm{K}_{2} \mathrm{ReOCl}_{5}$ precursor according to the method reported elsewhere [17]. The concentration of metal ion solution was determined spectrophotometrically at wavelength $(\lambda)$ of $480 \mathrm{~nm}$. A pure AZ and CE drugs were purchased from the local market (El-Nasr Pharm. Chem. Co., Egypt), potassium iodide and $\mathrm{HCl}$ (36.4\%) was purchased from BDH.

\section{Titration method}

Potentiometric titrations were performed using a R3003 voltage comparator. A platinum plate was used as an indicator electrode. The redox system consisting of $\mathrm{AZ}$ and $\mathrm{CE}$ was created by oxidizing a small portion of the initial drugs in $0.3 \mathrm{M} \mathrm{HCl}$ with $0.1 \mathrm{~N}$ iodine solution $(0.5 \mathrm{~mL})$. The stepwise complexes of $\mathrm{Re}(\mathrm{V})$ with $\mathrm{AZ}$ and $\mathrm{CE}$ were studied using the Bjerrum method [18, 19]. For this purpose, the redox system consisting of the drugs $(0.04192 \mathrm{~mol} / \mathrm{L})$ and its oxidized form titrated with a $\mathrm{K}_{2} \mathrm{ReOCl}_{5}$ solution $(0.0799 \mathrm{~mol} / \mathrm{L})$ in $0.3 \mathrm{M} \mathrm{HCl}$. The 
equilibrium ligand concentration ([L]) and the formation function $(\bar{n})$ at each titration point was calculated using the equations (1) and (2) [20,21], respectively:

$$
\begin{aligned}
& \log [L]=\frac{E_{I}-E_{i}}{1.9837 \times 10^{-4} T}+\log C_{L}^{I}+\frac{1}{2} \log \frac{V_{I}}{V_{T}} \\
& \bar{n}=\frac{C_{L}^{I}-[L]}{C_{M}}
\end{aligned}
$$

where, $E_{\mathrm{I}}$ and $\mathrm{E}_{\mathrm{i}}$ are the initial equilibrium potentials of the system in the absence of metal ion and at the current titration point, $C_{L}^{1}$ is the drug initial concentration of, $\mathrm{V}_{\mathrm{I}}$ and $\mathrm{V}_{\mathrm{T}}$ are the initial and total volumes, respectively, $\mathrm{T}$ is the temperature in $\mathrm{K}$ and $\mathrm{C}_{\mathrm{M}}$ is the concentration of metal ion at each titration point.

The stepwise stability constants $\left(\log \mathrm{K}_{\mathrm{i}}\right)$ of the complexes were calculated at half-integer values of the degree of formation. Thus, a large equilibrium constant indicates a highly stable complex. The overall stability constant ( $\beta \mathrm{i})$ defined as the following equation 3 [22]:

$$
\log \beta_{i}=\log K_{1}+\log K_{2}+\log K_{3} \ldots \ldots .+\log K_{i}
$$

The $\log \mathrm{K}_{\mathrm{i}}$ of the complexes was calculated at $288,298,308$ and $318 \mathrm{~K}$.

The complex formation thermodynamic characteristics such as: enthalpy $(\Delta \mathrm{H})$, Gibb's free energy $(\Delta \mathrm{G})$ and entropy $(\Delta \mathrm{S})$ are a fundamental important properties of understanding of the various factors such as electronic and steric effects, solute-solvent interactions that may influence on the complexes [23]. The thermodynamic parameters of the metal ion complexes at $288,298,308$, and $318 \mathrm{~K}$ were studied. The complex degree of formation was obtained according to the equations (4) and (5) [24, 25]:

$$
\begin{aligned}
& \Delta G=\Delta H-T \Delta S \\
& \log K_{i}=\frac{-\Delta H}{2.303 R}+\frac{1}{T} \times \frac{\Delta S}{2.303 R}
\end{aligned}
$$

where, $\mathrm{R}$ is the ideal gas constant $(8.314 \mathrm{~J} / \mathrm{K} \mathrm{mol}) . \Delta \mathrm{H}$ and $\Delta \mathrm{S}$ were obtained from the intercept and slope of the plot of $\log \mathrm{K}_{\mathrm{i}}$ against $1 / \mathrm{T}$.

\section{Potentiometric titration}

\section{Results and Discussion}

The metal ion in solution excites as combined with ligands or chelating groups instead of isolated form, giving rise to complexions or coordination compounds. The obtained titration data were analyzed and then stability constant values were calculated [26]. The experimental data show that the equilibrium potential of the redox system increases in the process of potentiometric titration as the metal ion volume increases. During the titration, no precipitates were formed indicating that there is no tendency to form hydroxide complexes [27]. Intense coloration was observed, which indicated the complexes formation. The formation curves were plotted between $\bar{n}$ and $-\log$ [L]. The coordination process in the systems $\mathrm{Re}(\mathrm{V})-\mathrm{AZ}$ and $\mathrm{Re}(\mathrm{V})-\mathrm{CE}$ in $0.3 \mathrm{M} \mathrm{HCl}$ at various temperatures were characterized by the formation curves as displayed in Figure 1.

$\operatorname{Re}(\mathrm{V})$ exists in solutions and solids as octahedral species [28, 29]. In this study, the obtained complexes of $\operatorname{Re}(\mathrm{V})$ with $\mathrm{AZ}$ and $\mathrm{CE}$ have a coordination number of six [30,31]. AZ is considered as neutral and monodentate ligand and the coordination bonds occur between the lone pair of sulfur atom and $\operatorname{Re}(\mathrm{V})$ [32]. The $\operatorname{Re}(\mathrm{V})-\mathrm{AZ}$ system has a maximum value of $\bar{n}=4$, this indicates the formation 1:2, 1:3 and 1:4 complexes. While about 1:1 complex has not formed. The complex formation suggests a successive displacement of the chloride molecules from the coordination sphere of the central ion by the AZ and CE ligands [33]. The maximum value of $\bar{n}$ in the $\operatorname{Re}(\mathrm{V})-\mathrm{CE}$ system was 2 , this shows the formation of 1:1 and 1:2 complexes. On the other hand, CE loses one sodium atom and becomes anionic. In case of 1:1 complex, $\operatorname{Re}(\mathrm{V})$ unit is coordinated by a mono anionic O,O-bidentate unit of CE ligand, one 
$\mathrm{CE}$ and three halogens, with $\operatorname{Re}(\mathrm{V})$ center in a distorted octahedral environment. The halide ligands are in cis positions to each other $[34,35]$. The proposed mechanism of the $\operatorname{Re}(\mathrm{V})-\mathrm{CE}$ complex formation process $1: 1$ and 1:2 ratios according to the following reaction (Scheme 2). The estimated $\log \mathrm{K}_{\mathrm{i}}$ values of $\operatorname{Re}(\mathrm{V})$ complexes with $\mathrm{AZ}$ and $\mathrm{CE}$ at different temperatures are listed in Table 1.

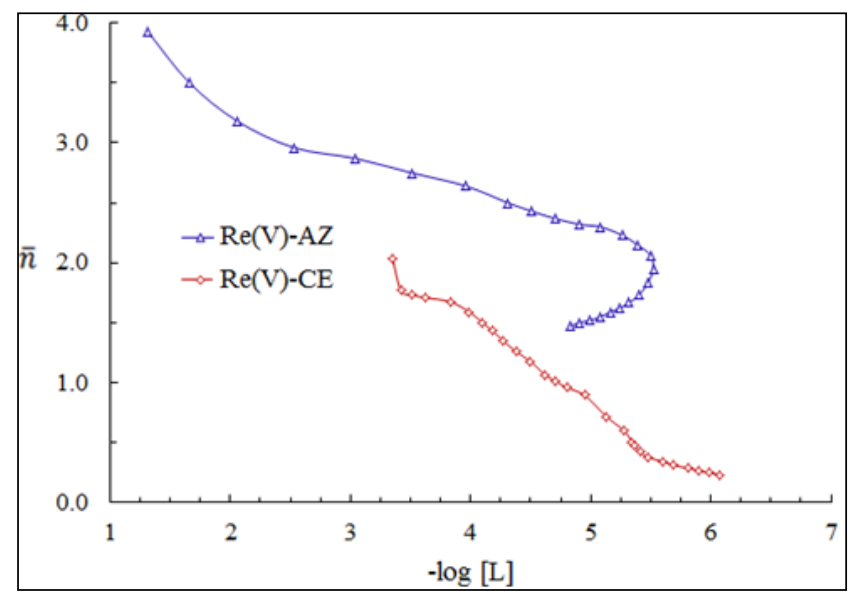

Figure 1. Formation curves of $\mathrm{Re}(\mathrm{V})$ complexes with $\mathrm{AZ}$ and $\mathrm{CE}$ in $0.3 \mathrm{M} \mathrm{HCl}$ at $318 \mathrm{~K}$

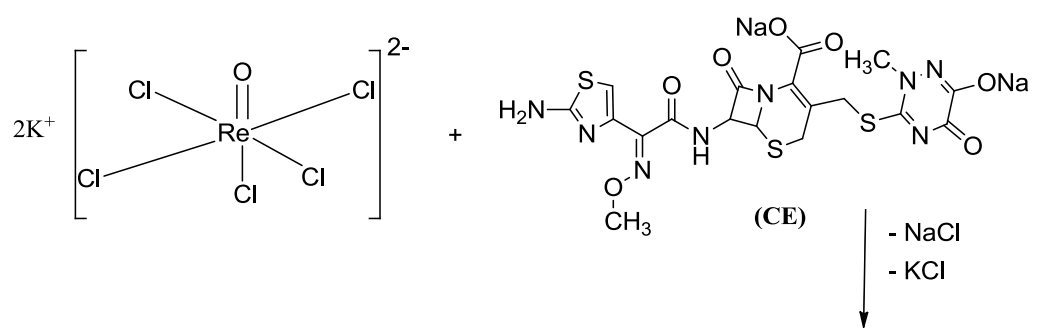

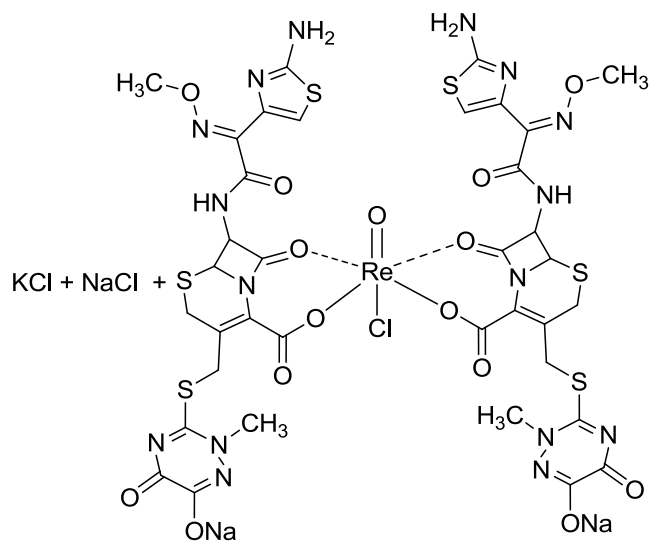

$\left[\mathrm{ReO}(\mathrm{CE})_{2} \mathrm{Cl}\right],(1: 2)$

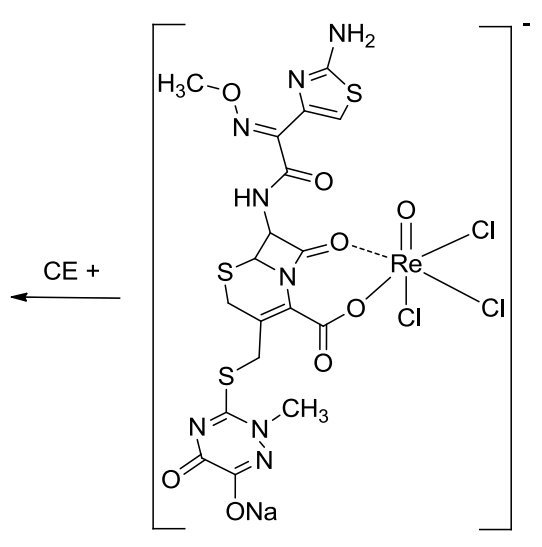

$\left[\mathrm{ReO}(\mathrm{CE}) \mathrm{Cl}_{3}\right]^{-},(1: 1)$

Scheme 2. The chelation between the $\left[\mathrm{ReOCl}_{5}\right]^{2-}$ and $\mathrm{CE}$ 
Table 1. Stepwise stability constants of $\operatorname{Re}(\mathrm{V})$ complexes in $0.3 \mathrm{M} \mathrm{HCl}$

\begin{tabular}{lccccccc}
\hline \multirow{2}{*}{$\mathbf{T}(\mathbf{K})$} & \multicolumn{4}{c}{$\operatorname{Re}(\mathbf{V})-\mathbf{A Z}$} & \multicolumn{3}{c}{$\operatorname{Re}(\mathbf{V})-\mathbf{C E}$} \\
\cline { 2 - 8 } & $\log \mathbf{K}_{\mathbf{2 A Z}}$ & $\log \mathbf{K}_{\mathbf{3 A Z}}$ & $\log \mathbf{K}_{\mathbf{4 A Z}}$ & $\log \boldsymbol{\beta}_{\mathbf{i A Z}}$ & $\log \mathbf{K}_{\mathbf{1 C E}}$ & $\log \mathbf{K}_{\mathbf{2 C E}}$ & $\log \boldsymbol{\beta}_{\mathbf{i C E}}$ \\
\hline 288 & 5.93 & 5.30 & 1.82 & 13.05 & 6.66 & 4.95 & 11.61 \\
298 & 5.84 & 5.13 & 1.77 & 12.72 & 6.34 & 4.67 & 11.01 \\
308 & 5.32 & 4.66 & 1.72 & 11.63 & 6.11 & 4.33 & 10.44 \\
318 & 4.91 & 4.31 & 1.66 & 10.84 & 5.35 & 4.10 & 9.45 \\
\hline
\end{tabular}

It is observed from Table 1 that, the temperature increase leads to decreasing in $\log \beta_{\mathrm{i}}$ values for both $\mathrm{AZ}$ and CE. It could be seen from data in all the cases that the differences between $K_{1}, K_{2}, K_{3}$ and $K_{4}$ values are found to be high which indicate the formation of the stepwise complex. The value of the ratio of $\log K_{1} / \log K_{2}$ or $\log K_{2} / \log K_{3}$ is positive in all the cases. This implies that there is no steric hindrance to the addition of a secondary ligand molecule [36]. This is due to the statistically effective and statistically coordination of a second molecule is difficult when compared to the first due to the availability of less number of coordinating sites on the metal ion for the second ligand [37].

\section{Complexes thermodynamic}

The chemical species in the reaction undergo a change in their concentrations, at the same time. The Gibb's free energy is a function of the concentrations of reactants and products. Entropy is a measure of energy that is unavailable for useful, chemical work. The entropy of an individual species is always positive and tends to be larger for gases than for solids, and for more complex molecules than for simple molecules. The thermodynamic parameters values of $\operatorname{Re}(\mathrm{V})-\mathrm{AZ}$ and $\operatorname{Re}(\mathrm{V})-\mathrm{CE}$ complexes have been calculated from the temperature dependent data given in Table 1.

The thermodynamic data were plotted as the values of equilibrium constants $\left(\log \mathrm{K}_{\mathrm{i}}\right)$ versus the reciprocal of temperature (1/T) as shown in Figures 2 and 3 for AZ and CE complexes, respectively. All the thermodynamic parameters of the stepwise stability constants of the complexes are given in Table 2.

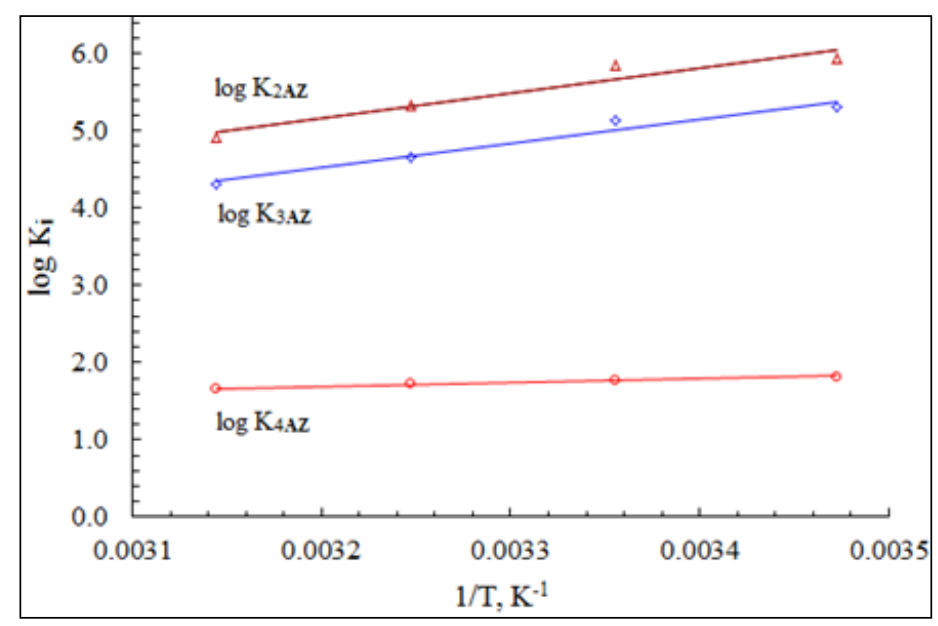

Figure 2. The relations between the values of equilibrium constants $\left(\log \mathrm{K}_{\mathrm{i}}\right)$ versus the reciprocal of temperature (1/T) of $\mathrm{Re}(\mathrm{V})-\mathrm{AZ}$ complexes: $\log \mathrm{K}_{2}$ corresponds to $\left[\mathrm{ReO}(\mathrm{AZ})_{2} \mathrm{Cl}_{3}\right]$; $\log \mathrm{K}_{3}$ corresponds to $\left[\mathrm{ReO}(\mathrm{AZ})_{3} \mathrm{Cl}_{2}\right]^{+}$and $\log \mathrm{K}_{4}$ corresponds to $\left[\mathrm{ReO}(\mathrm{AZ})_{4} \mathrm{Cl}\right]^{2+}$ species 


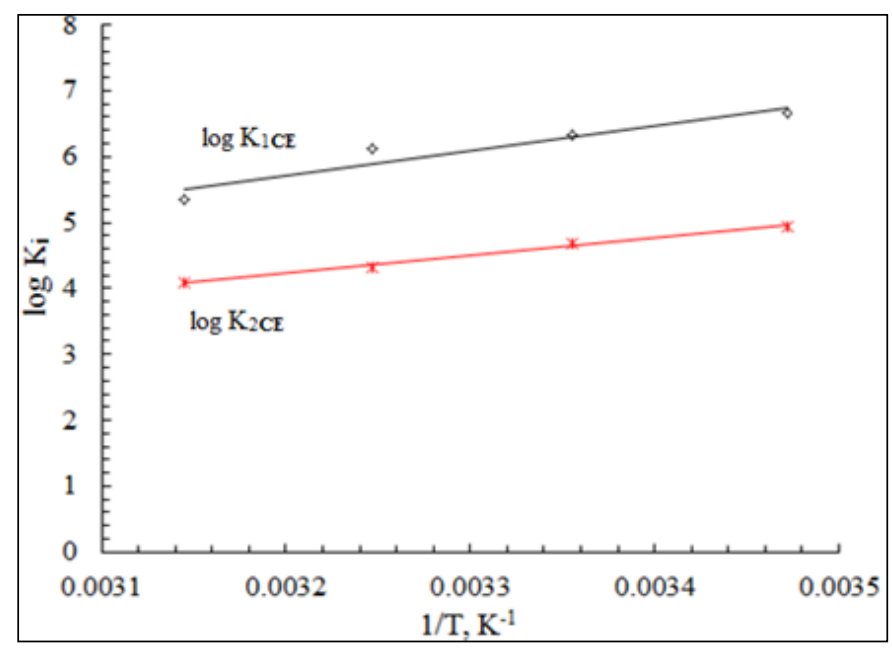

Figure 3. The relations between the values of equilibrium constants $\left(\log \mathrm{K}_{\mathrm{i}}\right)$ versus the reciprocal of temperature $(1 / \mathrm{T})$ of $\mathrm{Re}(\mathrm{V})-\mathrm{CE}$ complexes: $\log \mathrm{K}_{1}$ corresponds to $\left[\mathrm{ReO}(\mathrm{CE}) \mathrm{Cl}_{3}\right]^{-}$and $\log \mathrm{K}_{2}$ corresponds to $\left[\mathrm{ReO}(\mathrm{CE})_{2} \mathrm{Cl}\right]$ species

Table 2. Thermodynamic parameters of $\mathrm{Re}(\mathrm{V})$ complexes with $\mathrm{AZ}$ and $\mathrm{CE}$ in $0.3 \mathrm{M} \mathrm{HCl}$

\begin{tabular}{lccc}
\hline Species & $\begin{array}{c}-\Delta \mathbf{G} \\
(\mathbf{k J} / \mathbf{m o l})\end{array}$ & $\begin{array}{c}-\Delta \mathbf{H} \\
(\mathbf{k J} / \mathbf{m o l})\end{array}$ & $\begin{array}{c}\Delta \mathbf{S} \\
(\mathbf{J} / \mathbf{K} \mathbf{m o l})\end{array}$ \\
\hline$\left[\mathrm{ReO}(\mathrm{AZ})_{2} \mathrm{Cl}_{3}\right]$ & 32.32 & 62.36 & -100.78 \\
{$\left[\mathrm{ReO}(\mathrm{AZ})_{3} \mathrm{Cl}_{2}\right]^{+}$} & 28.58 & 60.07 & -105.66 \\
{$\left[\mathrm{ReO}(\mathrm{AZ})_{4} \mathrm{Cl}^{2+}\right.$} & 10.08 & 92.76 & 2.71 \\
{$\left[\mathrm{ReO}(\mathrm{CE}) \mathrm{Cl}_{3}\right]^{-}$} & 35.99 & 72.40 & -12.18 \\
{$\left[\mathrm{ReO}(\mathrm{CE})_{2} \mathrm{Cl}\right]$} & 26.51 & 50.70 & -81.60 \\
\hline
\end{tabular}

The stepwise formation constants of complexes of the type $M L_{n}$ (where $M$ is the metal, $L$ is the ligand and $n$ is the number of ligands) decrease in magnitude as $n$ increases. This may be partly explained in terms of the entropy factor. In the case of the formation of octahedral complexes of $\mathrm{Re}(\mathrm{V})-\mathrm{AZ}$, the reaction between $\mathrm{K}_{2}\left[\mathrm{ReOCl}_{5}\right]$ and $\mathrm{AZ}$ involves three successive reactions as the following equations (6-8).

$$
\begin{gathered}
\mathrm{K}_{2}\left[\mathrm{ReOCl}_{5}\right]+2 \mathrm{AZ} \leftrightharpoons\left[\operatorname{ReO}(\mathrm{AZ})_{2} \mathrm{Cl}_{3}\right]+2 \mathrm{KCl} \\
{\left[\mathrm{ReO}(\mathrm{AZ})_{2} \mathrm{Cl}_{3}\right]+\mathrm{AZ} \leftrightharpoons\left[\operatorname{ReO}(\mathrm{AZ})_{3} \mathrm{Cl}_{2}\right] \mathrm{Cl}} \\
{\left[\mathrm{ReO}(\mathrm{AZ})_{3} \mathrm{Cl}_{2}\right] \mathrm{Cl}+\mathrm{AZ} \leftrightharpoons\left[\mathrm{ReO}(\mathrm{AZ})_{4} \mathrm{Cl}_{\mathrm{Cl}_{2}}\right.}
\end{gathered}
$$

In equation (6), the two ligands ( $n=2)$ can go into two cites out of five of $\mathrm{K}_{2}\left[\mathrm{ReOCl}_{5}\right]$. For equation (8), $n=4$ and the fourth ligand can go into one of two sites of $\mathrm{K}_{2}\left[\mathrm{ReOCl}_{5}\right]$. This means that there is more randomness in the first step than the fourth one, so $\Delta \mathrm{S}$ is more positive (2.71), $\Delta \mathrm{H}$ is more negative (-92.76) and $\log K_{2}>\log K_{4}$ [38]. In addition, there is a dramatic increase in $\Delta \mathrm{S}$ for adding two compared to adding four monodentate AZ ligands (100.78 to $2.71 \mathrm{~J} / \mathrm{K} \mathrm{mol}$ ) which changed from negative (unfavorable) to positive (favorable). Using the equilibrium constant for the complex formation of $\operatorname{Re}(\mathrm{V})-\mathrm{CE}$ where the one and two bidentates ligand replace the monodentates chloride ions, it has been found the $\Delta \mathrm{S}$ decrease (-12.18 to -81.60). The negative change in $\Delta \mathrm{S}$ indicates a highly solvated metal complex and indicated that the formation of these complexes was entropy favored [39, 40]. $\Delta \mathrm{H}$ 
change for the complexes suggests that all the complexation reactions releasing heat have a negative value (exothermic), favorable at a lower temperature. The metal-ligand binding process is enthalpy driven and metalligand bonds are strong [41]. The sign of $\Delta \mathrm{G}$ indicates the direction in which a reaction moves to reach its equilibrium position. The complexation reactions are thermodynamically favorable when its enthalpy decreases and its entropy increase. Substituting the inequalities $\Delta \mathrm{H}<0$ and $\Delta \mathrm{S}>0$ into the previous equation (4) shows that complexation reactions are thermodynamically favorable and spontaneous when $\Delta \mathrm{G}$ is negative [42]. Similar trend was obtained for $\operatorname{Re}(\mathrm{V})$ with another ligand [38].

\section{Distribution diagrams}

Mole fractions are commonly used to calculate the concentrations of the individual complexes based on the formation constants. Mole fractions of a form of the complex compressed as the ratio of the concentration of the complex to the total concentration of the metal ion. The distribution diagrams were drawn in the titration where the $\operatorname{Re}(\mathrm{V})$ to ligands, mole ratio was 1:1, 1:2, 1:3 and 1:4 at $318 \mathrm{~K}$ (Figure 4). It was obtained using Microsoft Excel calculations [43] and the concentration of total metal ions $(0.0799 \mathrm{~mol} / \mathrm{L})$ was set as $100 \%$.

In Figure 4, the species $\left[\mathrm{ReO}(\mathrm{AZ})_{2} \mathrm{Cl}_{3}\right.$ ] for the system $\mathrm{Re}(\mathrm{V})-\mathrm{AZ}$ reached a maximum of $2.9 \%$. The second species $\left[\mathrm{ReO}(\mathrm{AZ})_{3} \mathrm{Cl}_{2}\right]^{+}$and $\left[\mathrm{ReO}(\mathrm{AZ})_{4} \mathrm{Cl}\right]^{2+}$ reached a maximum of $85.3 \%$ and $96.6 \%$, respectively. For $\mathrm{Re}(\mathrm{V})-\mathrm{CE}$ system, it reached a maximum of $67.5 \%$ and $99.89 \%$ for $\left[\mathrm{ReO}(\mathrm{CE}) \mathrm{Cl}_{3}\right]^{-}$and $\left[\mathrm{ReO}(\mathrm{CE})_{2} \mathrm{Cl}\right]$ species, respectively. The analysis of the temperature-dependent distribution function shows that the yield of the complexes decreases with increasing the temperature. The analysis of the distribution curves provides the possibility to elucidate the predominance region for some complex depending on temperature and concentration. These results were used to develop optimal methods for the preparation of $\mathrm{Re}(\mathrm{V})$ metal ion complexes with $\mathrm{AZ}$ and $\mathrm{CE}$ in $0.3 \mathrm{M} \mathrm{HCl}$.

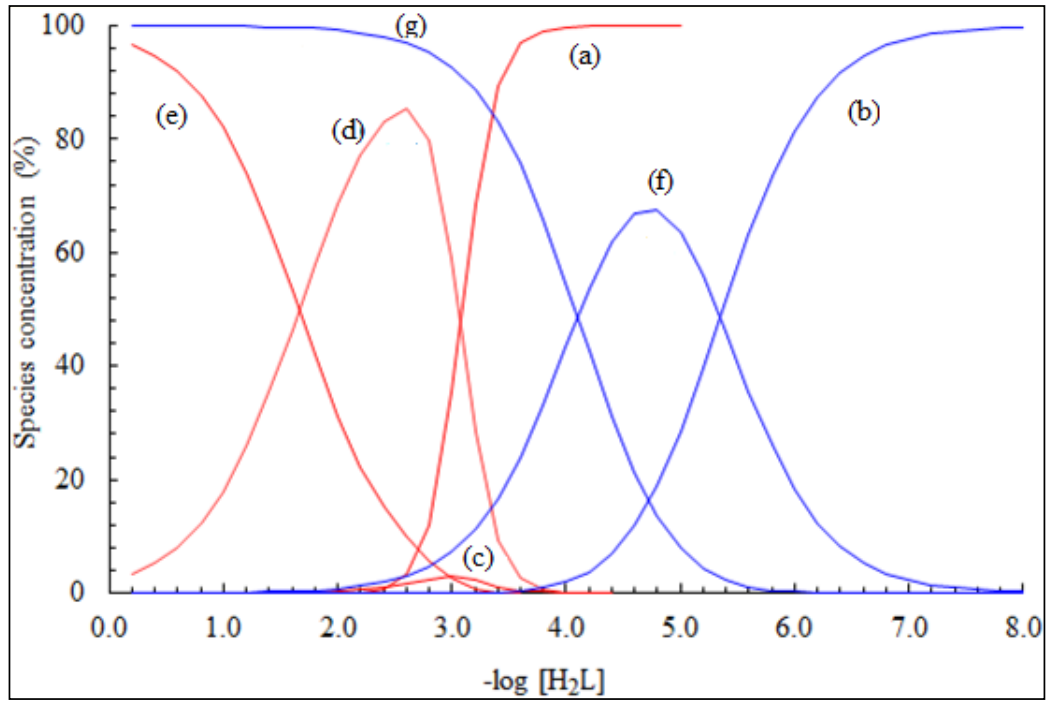

Figure 4. Distribution curves of $\operatorname{Re}(\mathrm{V})$ complexes with $\mathrm{AZ}$ and $\mathrm{CE}$ at $318 \mathrm{~K}$ for $\left[\mathrm{ReOCl}_{5}\right]^{2-}$ (a) and (b), $\left[\mathrm{ReO}(\mathrm{AZ})_{2} \mathrm{Cl}_{3}\right](\mathrm{c}),\left[\mathrm{ReO}(\mathrm{AZ})_{3} \mathrm{Cl}_{2}\right]^{+}(\mathrm{d}),\left[\mathrm{ReO}(\mathrm{AZ})_{4} \mathrm{Cl}\right]^{2+}(\mathrm{e}),\left[\mathrm{ReO}(\mathrm{CE}) \mathrm{Cl}_{3}\right]^{-}$(f) and $\left[\mathrm{ReO}(\mathrm{CE})_{2} \mathrm{Cl}\right](\mathrm{g})$

\section{Conclusion}

The potentiometric study investigated the behavior of complex formation of $\operatorname{Re}(\mathrm{V})$ metal ion with azathioprine (AZ) and ceftriaxone (CE). AZ is a neutral and monodentate ligand and the coordination bonds occur between the lone pair of sulfur atom with $\operatorname{Re}(\mathrm{V})$. $\operatorname{Re}(\mathrm{V})-\mathrm{AZ}$ system has a maximum value of $\bar{n}$ of 4 , this showed the formation 1:2, 1:3 and 1:4 complexes. The complex formation suggests a successive displacement of the chloride molecules from the coordination sphere of the central ion by the AZ ligand. The maximum value of $\bar{n}$ in the system of $\operatorname{Re}(\mathrm{V})-\mathrm{CE}$ was 2, this showed the formation 1:1 and 1:2 complexes. The CE is losing one sodium atom and becomes anionic 
ligand. The increasing amount coordinated molecules $\mathrm{AZ}$ and $\mathrm{CE}$ and the temperature the values $\log \mathrm{K}_{\mathrm{i}}$ decreases. There is a dramatic increase $\Delta \mathrm{S}$ for adding two compared to adding four monodentate AZ ligands (-100.78 to 2.71 $\mathrm{J} / \mathrm{K} \mathrm{mol}$ ) which change from negative (unfavorable) to positive (favorable). The enthalpy change $(\Delta \mathrm{H})$ for the complexes suggests that all the complexation reactions releasing heat have a negative $\Delta \mathrm{H}$ (exothermic), favorable at low temperatures. $\Delta \mathrm{G}$ indicates the direction in which a reaction moves to reach its equilibrium position. The above mentioned parameters and results will be useful in understanding the biological behavior of these complexes in the biological applications.

\section{Acknowledgement}

The authors would like to thank Chemistry department, Faculty of Science, Al-Azhar University, Assiut, Egypt for providing the facilities of this work.

\section{References}

1. Thomas, G. (2003). Fundamentals of medicinal chemistry. John Wiley \& Son Ltd. London, UK.

2. Mendham, J. (2006). Vogels textbook of quantitative chemical analysis. Pearson Education India.

3. Kinlen, L. J. (1985). Incidence of cancer in rheumatoid arthritis and other disorders after immunosuppressive treatment. American Journal of Medicine, 78(1): $44-49$.

4. Fries, J. F., Bloch, D., Spitz, P. and Mitchell, D. M. (1985). Cancer in rheumatoid arthritis: A prospective longterm study of mortality. American Journal of Medicine, 78(1): 56 - 59.

5. Kotton, C. N. and Hibberd, P. L. (2009). Travel medicine and the solid organ transplant recipient. American Journal of Transplantation, 9(4): $273-281$.

6. Rind, F. M. A., Laghari, M. G. H., Memon, A. H., Mughal, U. R., Almani, F. N., Memon, K. M. Y. and Maheshwari, M. L. (2008). Spectrophotometric determination of ceftriaxone using 4dimethylaminobenzaldehyde. Pakistan Journal of Analytical \& Environmental Chemistry, 9(1): 43 - 48.

7. Al-Momani, I. F. (2001). Spectrophotometric determination of selected cephalosporins in drug formulations using flow injection analysis. Journal of Pharmaceutical and Biomedical Analysis, 25(5-6): 751 - 757.

8. Lampros, R., Georgios, P. and Nikolaos, A. (2006). Use of ceftriaxone in patients with severe leptospirosis. International Journal of Antimicrobial Agents, 28(3): 259 - 261.

9. Hirn, M., Laitinen, M., Pirkkalainen, S. and Vuento, R. (2004). Cefuroxime, rifampicin and pulse lavage in decontamination of allograft bone. Journal of Hospital Infection, 56(3): 198 - 202.

10. Saranjit, S., Monica, G. and Gupta, R. L. (1991). Complexation behaviour of azathioprine with metal ions. International Journal of Pharmaceutics, 68(1-3): 105 - 110.

11. Singh, B. N. and Kim, K. H. (2005). Effects of divalent cations on drug encapsulation efficiency of deacylated gellan gum. Journal of Microencapsulation, 22(7): 761 - 771.

12. Okoronkwo, A. E. and Aminjanov, A. A. (2005). Study of the step wise complexation processes of rhenium(V) and 2-mercapto pyridine in 6 moles/L HBr. Oriental Journal of Chemistry, 21(1): $49-57$.

13. Al-Sawaad, H. Z. (2013). Evaluation of the ceftriaxone as corrosion inhibitor for carbon steel alloy in $0.5 \mathrm{M}$ of hydrochloric acid. International Journal of Electrochemical Science, 8(3): $3105-3120$.

14. Doadrio, A. L., Antonio, M. and Regina, O. (2002). $\mathrm{VO}^{2+}$ and $\mathrm{Cu}^{2+}$ interactions with ceftriaxone and ceftizoxime: HPLC kinetic studies. Journal of the Brazilian Chemical Society, 13(1): 95 - 100.

15. Gouda, G. A. H. (2014). Stability constants of rhenium (V) metal complexes with selected medicinal drugs. Pyrex Journal of Research in Environmental Studies, 1(2): 6 - 14.

16. Roberts, N. A. and Robinson, P. A. (1985). Copper chelates of antirheumatic and anti-inflammatory agents: their superoxide dismutase-like activity and stability. British Journal of Rheumatology, 24(2): 128 - 136.

17. Jezowska-Trzebiatowska, B., Wajda, S. and Baluka, M. (1968). Structure and properties of technetium and rhenium compounds of the type $\left[\mathrm{MeVOX}_{5}\right]^{2-}$ I. Preparation and magnetic and spectrophotometric study. Journal of Structural Chemistry, 8(3): $456-459$.

18. Bjerrum, J. (1941). Metal amine formation in aqueous solution; Hasse P. Son. Copenhagen, Denmark.

19. Irving, H. M. and Rossotti, H. S. (1954). The calculation of formation curves of metal complexes from $\mathrm{pH}$ titration curves in mixed solvents. Journal of the Chemical Society, 1954: $2904-2910$.

20. Feiner, A. S. and McEvoy, A. J. (1994). The Nernst equation. Journal of Chemical Education, 71(6): 493 494. 
21. Thompson, M. L. and Kateley, L. J. (1999). The Nernst equation: Determination of equilibrium constants for complex ions of silver. Journal of Chemical Education, 76(1): 95 - 96.

22. Heuron, J. Z. and Gilbert, J. B. (1955). New methods for the calculation of association constants of complex ion systems. Journal of the American Chemical Society, 77(9): 2594 - 2596.

23. Nair, V. S. K. and Parthasarathy, S. (1971). Studies on metal complexes in aqueous solution-VII: 4-nitro and 4methyl phthalates of some transition metals. Journal of Inorganic and Nuclear Chemistry, 33(9): 3019 - 3020.

24. Ives, D. J. G. (1971). Chemical thermodynamics. Macdonald and Co. Ltd., London, UK.

25. Seaf Elnasr, T. A., Soliman, M. H. and Ayash, M. A. A. (2017). Modified hydroxyapatite adsorbent for removal of iron dissolved in water wells in Sohag, Egypt. Chemistry of Advanced Materials, 2(1): $1-13$.

26. Omar, A. A. and Ali, E. A. (2014). Titanium carboxylate complexes stability constants estimated by four graphical methods. International Journal of Basic and Applied Sciences, 3(4): 497 - 503.

27. Golcu, A., Tumer, M., Demirelli H. and Wheatley, R. A. (2005). Cd(II) and Cu(II) complexes of polydentate Schiff base ligands: synthesis, characterization, properties and biological activity. Inorganica Chimica Acta, 358(6): $1785-1797$.

28. Santos, I. G. and Abram, U. (2004). Oxorhenium(V) complexes with thiosemicarbazones. Zeitschrift für Anorganische und Allgemeine Chemie, 630(5): 697 - 700.

29. David, J. H., Jonathan, M. W., Catriona, A. M., Victor, L. V., Kevin, J. B. and Paul, S. D. (2016). Synthesis of oxorhenium $(\mathrm{V})$ and oxotechnetium $(\mathrm{V})$ complexes that bind to amyloid- $\beta$ plaques. Inorganic Chemistry, 55(16): $7944-7953$.

30. Smith, K. J., Ondracek, A. L., Gruhn, N. E., Lichtenberger, D. L., Fanwick, P. E. and Walton, R. A. (2000). A comparative study of the isomers of $\mathrm{ReOCl}_{3}\left(\mathrm{PMe}_{3}\right)_{2}$ and $\mathrm{ReOCl}_{3}\left(\mathrm{PEt}_{3}\right)_{2}$. The isolation and characterization of $\mathrm{ReH}_{7}\left(\mathrm{PR}_{3}\right)_{2}$ and $\mathrm{ReO}(\mathrm{OEt}) \mathrm{Cl}_{2}\left(\mathrm{PR}_{3}\right)_{2}\left(\mathrm{R}=\mathrm{Me}\right.$ or Et) and the photoelectron spectrum of $\mathrm{ReH}_{7}\left(\mathrm{PMe}_{3}\right)_{2}$. Inorganica Chimica Acta, 300: 23 - 31.

31. Xiaoyuan, C., Frank, J. F., John, B. W. and Babich, J. Z. (2000). Exploring oxorhenium ' $3+1$ ' mixed-ligand complexes carrying the S-benzyl-3-[(2-hydroxyphenyl)methylene]dithiocarbazate [ONS]/monothiol [S] donor set: Synthesis and characterization. Inorganica Chimica Acta, 307(1-2): $154-159$.

32. Berthold, N., Hans, P., Francesco, T., Theodosia, M., Peter, L., Hartmut, S. and Chiotellis, E. (2000). Oxorhenium mixed-ligand complexes with the 2,6-dimercaptomethylpyridine ligand. Crystal structure of [2,6dimercaptomethylpyridinato][p-methoxybenzenethiolato]oxorhenium(V). Inorganica Chimica Acta, 304(1): 26 -32 .

33. Conner, K. A., Walton, R. A., Wilkinson, G., Gillard, R. D. and McCleverty, J. A. (1987). Comprehensive coordination chemistry. Pergamon, Oxford, UK.

34. André, G. A., Fernandes, Pedro, M. I. S., Elizeu, S. J., Sebastião, L. S., Alzir, B. A. Abram, U., Ellena, J., Eduardo, C. E. and Victor, D. M. (2008). Rhenium chelate complexes with maltolate or kojate. Polyhedron, 27(13): $2983-2989$.

35. Ondracek, A. L., Fanwick, P. E. and Walton, R. A. (1998). The synthesis, characterization and X-ray crystal structures of the fac-cis and mer-trans isomers of $\mathrm{ReOCl}_{3}\left(\mathrm{PMe}_{3}\right)_{2}$. Inorganica Chimica Acta, 267(1): 123 - 126.

36. Mowafak, M. M., Abeer, A. T., Ahmed, E. A. and Mohamed, S. M. (2015). Potentiometric and thermodynamic studies for binary and mixed ligand complexes of some transition metal ions with hydrazone and phenylalanine. International Journal of Electrochemical Science, 10(1): 456 - 471.

37. Jamode, V. S. and Kale, A. S. (2007). Stability constant of transition metal ions complex with1-carboxamido3,5-diaryl-4-aroylpyrazoles. Asian Journal of Chemistry, 19(1): 787 - 789.

38. Gouda, G. A. H., Ali, G. A. M. and Seaf-Elnasr, T. A. (2015). Stability studies of selected metal ions chelates with 2-(4-amino-1,5-dimethyl-2-phenyl-1,2-dihydro-pyrazol-3-ylideneamino) phenol. International Journal of Nanomaterials and Chemistry, 1(2): $39-44$.

39. Gouda, G. A. H. and Mahross, M. H. (2016). Potentiometric and quantum chemical studies of some metal complexes with 2-(4-amino-1,5-dimethyl-2-phenyl-1,2-dihydro-pyrazol-3-ylideneamino) phenol. Global Journal of Multidisciplinary Studies, 5: $164-180$.

40. Park, H., Choi, W., Cotton, F. A., Wilkinson, G. and Gaus, P. L. (1995). Basic inorganic chemistry. John Wiley $\&$ Sons Inc.

41. Sharmeli, Y. and Lonibala, R. (2009). Thermodynamics of the complexation of n-(pyridin-2-ylmethylene) isonicotinohydrazide with lighter lanthanides. Journal of Chemical \& Engineering Data, 54(1): 28 - 34. 
Gamal Abdelaziz \& Gomaa Abdelgawad : POTENTIOMETRIC STUDY OF RHENIUM(V) COMPLEX FORMATION WITH AZATHIOPRINE AND CEFTRIAXONE

42. Al-Sarawy, A. A., El-Bindary, A. A., El-Sonbati, A. Z. and Mokpel, M. M. (2006). Potentiometric and thermodynamic studies of azosulfonamide drugs. Polish Journal of Chemistry, 80(2): 289 - 295.

43. Martell, A. E. and Motekaitis, R. J. (1989). Determination and use of stability constants. Wiley-VCH, New York, USA. 